InterSedes, Revista electrónica de las sedes regionales de la Universidad de Costa Rica, ISSN 2215-2458, Vol XXI, Número 43, Enero - Julio, 2020.

10.15517/isucr.v21i43.41979 | intersedes.ucr.ac.cr | intersedes@ucr.ac.cr

\title{
GEAR UP: DESIGNING AN ESP COURSE FOR MECHANICAL ENGINEERING STUDENTS
}

\section{DISEÑO DE UN CURSO ESP PARA ESTUDIANTES DE INGENIERÍA MECÁNICA}

\author{
Jose Fabián Elizondo González ${ }^{1}$ \\ Yannick Pilgrim ${ }^{2}$ \\ Andrea Sánchez Víquez ${ }^{3}$
}

\begin{tabular}{l|l} 
Recibido: 02.04 .19 & Aprobado: 30.04.20
\end{tabular}

DOI: $10.15517 /$ isucr.v21i43.41979

\begin{abstract}
This article presents the design of the course Gear Up, an ESP course addressed to Mechanical Engineering students at the University of Costa Rica. To gather the necessary data, a needs analysis and a diagnostic test were conducted to determine the contents, macro-skills, and evaluated activities to be included in the course. This article presents the findings of these two major initial activities and the subsequent course design proposal to satisfy the needs, wants, and lacks of both the students and stakeholders that participated in the process. Consequently, Gear Up was created as a 16-week course in which the Task-Based Language Teaching approach would guide both the content and performance-based, assessed activities throughout the course.
\end{abstract}

Keywords: English for Specific Purposes; needs analysis; course design; Task-Based Language Teaching; performance assessment.

\section{Resumen}

Este artículo presenta el diseño del curso Gear $U p$, un curso de inglés para propósitos específicos dirigido a estudiantes del Bachillerato y Licenciatura en Ingeniería Mecánica en la Universidad de Costa Rica. Para recolectar los datos, se realizaron un análisis de necesidades y un examen de diagnóstico, esto con el fin de determinar los contenidos, las macro destrezas y las actividades evaluadas a incluir en el curso. Este artículo presenta los hallazgos de estas dos principales actividades iniciales; así como la propuesta del diseño de curso para satisfacer las necesidades de los estudiantes y los depositarios que participaron en el proceso. De esta forma, Gear Up se crea como un curso de dieciséis semanas en el cual el enfoque basado en tareas sería la guía tanto para

\footnotetext{
${ }^{1}$ Docente de Inglés, Escuela de Lenguas Modernas, Universidad de Costa Rica, San Pedro, San José, Costa Rica. Email: josefabianelizondo@gmail.com

${ }^{2}$ Máster en la Enseñanza del Inglés como Lengua Extranjera de la Universidad de Costa Rica, San José, Costa Rica. Docente de Inglés, Kamuk School, Tibás, San José, Costa Rica. Email: yanloupilg@gmail.com

${ }^{3}$ Docente de inglés del Programa Cursos de Conversación e Inglés por Áreas, Universidad de Costa Rica, San Pedro, San José, Costa Rica. Email: andreasanchezcr@gmail.com
} 
los contenidos del curso como para las actividades evaluadas en él, siguiendo los parámetros de la evaluación basada en el rendimiento.

Palabras clave: Inglés para fines específicos; análisis de necesidades; diseño de cursos; enfoque basado en tareas; evaluación basada en el rendimiento.

\begin{abstract}
In the last few decades, the non-stop technological innovations have sped up life's pace in general. Language teaching has changed as well, and the field of English for Specific Purposes (ESP) has met the need of providing particular populations with customized language courses that are designed to meet their needs, wants, and lacks, no matter how innovative or challenging these new fields might be. The Master's in Teaching English as a Foreign Language program at the University of Costa Rica (UCR) establishes as a requisite for graduation the creation, implementation, and evaluation of an ESP course during the second year of the program. The objective behind this is two-fold. On the one hand, it gives student-teachers in training the opportunity to conduct a needs analysis study to later design a course specifically suited for the needs of a specific student population, using the Task-Based Language Teaching (TBLT) approach. On the other hand, UCR students are given the chance of taking an English course that focuses on their immediate or delayed needs, which can be regarded as a very attractive feature, especially for young adults who have limited time to learn a second language. The population for this course design will be Mechanical Engineering students from Bachelor's and Licentiate degree from the University of Costa Rica.

In this document, we present two major sections. The first one deals with the needs analysis conducted at the beginning of the process. This initial section describes specific features of the ESP population, the students' English proficiency levels, as well as an analysis of their needs, wants, and lacks. The second section develops the rationale behind the course syllabus designed. More specifically, it details the course description, the goals to be achieved, and the methodology and assessment criteria to be used.
\end{abstract}

\title{
Literature Review
}

Task-based language teaching

Task-Based Language Teaching, or TBLT, promotes an approach to teaching that focuses on the processes required for students to achieve one specific outcome, rather than focusing on the 
mastery of grammar structures or pronunciation features. As explained by Skehan (1998), “in TBI [Task-Based Instruction], meaning is primary... the assessment of the task is in terms of outcome" and task-based instruction is not "concerned with language display" (p. 88). Due to the nature of this approach, curricula will be designed with a heavy emphasis on the completion of tasks. This does not mean that grammar and pronunciation are not important elements under this approach; what it entails is that these two latter features are acquired as byproducts, resulting from the interaction among students during a task.

Contrary to what some instructors believe, TBLT also proposes that learners have spaces to be given feedback on their language production during class. As described by Richards and Rodgers (2001), it is in the planning stage of the TBLT cycle that [the teacher] "goes around to advise students on language, suggesting phrases and helping Ss to polish and correct their language. The emphasis is on clarity, organization, and accuracy... Individual students often take this chance to ask questions about specific language items" (p. 239). Hence, learners can verify whether they have been using language to complete the tasks appropriately or not.

\section{Assessment of an ESP Course}

Formative, summative, and authentic assessment

Assessment, just like English teaching, has evolved over the last few decades. Since teaching is an interactive two-way performance, there is a constant need to prove that students have actually learned. Assessing is not an extra duty; instead, it becomes part of teaching itself. It is the way to determine if the teaching and the learning are effective on both ends. Huba and Freed (2000) propose a well-integrated assessment definition:

Assessment is the process of gathering and discussing information from multiple and diverse sources in order to develop a deep understanding of what students know, understand, and can do with their knowledge as a result of their educational experiences; the process culminates when assessment results are used to improve subsequent learning (p.15).

Huba and Freed's (2000) definition is pertinent to the student-teachers as it embodies an approach that uses a variety of authentic tasks to assess students in a way that guides learners toward the knowledge they need to perform these tasks efficiently. Assessing involves several key concepts that are often mixed up. For instance, terms such as tests, assessment, and evaluation are 
usually confused and even used as synonyms. Assessment also has several characteristics that define it, such as being an on-going process and having feedback as its main resource to enhance student learning (Wiggins, 1993).

Informal assessment

As described in Brown, H.D. (2004), "informal assessment can take a number of forms, starting with incidental, unplanned comments and responses, along with coaching and other impromptu feedback to the student" (p. 5) and for the student-teachers, this means that informal assessment is paramount to the development of the curriculum, as much of the interaction resulting from students' negotiation of meaning is spontaneous and unpredictable. Hence, the studentteachers must be ready to use informal assessment in classroom tasks "designed to elicit performance without recording results and making fixed judgments about a student's performance; [for example, by giving] suggestions for a strategy for compensating for a reading difficulty" (Brown, 2004, p.6). This description of informal assessment goes hand in hand with the principles for formative assessment. Brown (2004) elaborated on this by explaining that formative assessment it is characterized by:

Evaluating students in the process of forming their competencies and skills with the goal of helping them to continue that growth process. The key to such formation is the delivery... and internalization... of appropriate feedback on performance, with an eye toward the future continuation (or formation) of learning (p. 6).

Hence, formative assessment has a clear goal to improve the students' use of the language through feedback. Informal, formative assessment, then, is considered by the student-teachers as the core of a language curriculum.

Formal assessment

This type of assessment is defined as "exercises or procedures specifically designed to tap into a storehouse of skills and knowledge. They are systematic, planned sampling techniques constructed to give teacher and student an appraisal on student achievement" (Brown, 2004, p. 6). Summative assessment is more related to the formal assessment of students: through numbers that assign the "knowledge" acquired a value. It is called summative precisely because it measures, or 
adds, the results of formal evaluations in order to come up with a final grade. Tests in general, quizzes, midterms and others are examples of summative assessment. Another characteristic of summative assessment is that it determines specific knowledge in a specific time during the course or program, but it does not provide feedback or remedial plans for the results (Brown, 2004).

Needs Analysis
Procedures and instruments
Interview with the stakeholders

The course design process started by getting to know the stakeholders, in this case, the Director of the Mechanical Engineering School and the president of the Mechanical Engineering Students' Association. The communication with the Director has been limited to emails. The president of the Students' Association agreed on a virtual interview with the three student-teachers and he has been very effective on answering inquiries by email. He has also provided very important information about what the expectations for the course are, students' academic needs, and the characteristics of the work market that Mechanical Engineering students will eventually face.

Initial questionnaire for learners

An informative initial email was sent to the list of learners that a School of Mechanical Engineering provided. The email contained a brief description of the course, and it included a link to an online questionnaire. This questionnaire included items about personal information, learning preferences, proficiency perception, current academic needs and future work needs. The email was sent to 52 students, but only 31 of them completed the initial questionnaire. As the students were not required to take this course as part of their curriculum, the School of Mechanical Engineering did not ask them to participate mandatorily once the initial list was sent. 


\section{Diagnostic Test}

Once the initial information was collected, a second email was sent in order to convene the students to a Diagnostic Test (DT). The DT was applied at the language laboratories in the School of Modern Languages, and the learners were given three schedule options to take it. The DT had four parts: reading, listening, writing, and speaking. The DT invitation was sent to 31 students out of which 28 took the written test. The speaking component was evaluated through an individual conversation with one of the student-teachers via Skype. The learners were given the studentteachers' contact information and were contacted via Skype or phone on the scheduled date. Each learner talked with one of the student-teachers for about 15 to 20 minutes. Out of the 28 learners that took the written DT, only 20 contacted the student-teachers and completed the speaking part of the test.

The diagnostic test consisted of two parts, one written section and one oral section. The listening, reading, and writing macro skills were assessed in the written section, which in total accounted for $47 \%$ of students' final grade. The students were given one hour and a half to finish this part of the test.

The second part of the diagnostic test was mostly conducted over Skype. As some students could not install the program or reported to have connection problems, some of the interviews were conducted over the phone. This part of the test consisted of a conversation with one of the studentteachers to assess the speaking macro skill. Out of the students who took the written test, $87 \%$ contacted the student-teachers for the oral section. The other $13 \%$ students were contacted via email, but the researchers obtained no answers. This interview consisted of three warm-up questions and a role-play situation. Following Coombe, Folse, and Hubbley’s (2007) recommendations, the student-teachers designed an interview in which they would allow time for a warm-up, which would probably improve results, as it helps to put students at ease (p. 129), to get to know the students better, and to obtain some data on students' general oral proficiency. At the end of the conversation, there was one productive response item: an ESP-focused role-play situation. The student-teachers had the chance to choose amongst one of the three different role-play situations to assess each student. The role-play situation to be performed was selected by the student-teacher based on the students' areas of interest, brought up in the warm-up questions. The constructs taken into consideration were task completion, grammar, pronunciation, vocabulary, and fluency. 
To identify whether the students are beginners, intermediate, or advanced, the studentteachers included in each block of items different proficiency indicators for each major macro skill, adapting as guides the NCSSFL-ACFTL Can-Do Statements (American Council, 2015) and the ACTFL Oral Proficiency Interview Tester Training Manual (American Council, 2012). The student-teachers determined that the ACFTL proficiency guidelines would help them achieve this task better as "unlike the ACTFFL Proficiency Guidelines, the CEFR was not intended to serve as a framework for assessment [while]... the [ACTFL] guidelines are intended to be used for global assessment in academic and workplace settings" (American Council, 2012, p. ii).

General description of the Mechanical Engineering program and field of work

The School of Mechanical Engineering at the UCR was established in 1964 after the administration made the decision to separate the program from the electromechanical program. According to the Mechanical Engineering School's website, the creation of the Mechanical Engineering program emerged in response to the country's need for specialized engineers. The mission of the School of Mechanical Engineering is "to be recognized, on a national and regional level, as a producer of professionals in the area of Mechanical Engineering with high moral values, knowledge, and an investigative talent to promote technological, industrial, economic, and cultural

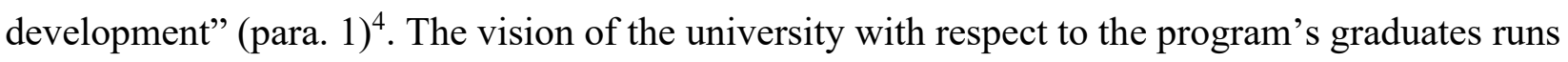
in the same vein. A graduate of the program is expected to be "a high performing professional able to produce recognized knowledge in Costa Rica and Central America" (para. 2) ${ }^{5}$. The vision goes on to explain that the graduate will have "outstanding self-management skills along with the ability to work in interdisciplinary teams" (para. 2). ${ }^{6}$

The university's mission and vision mentioned in the previous section provide an insight into the roles and expectations for the mechanical engineer. The methodology used by the university is one of group work and projects. This reflects real-life scenarios that engineers find themselves in on a day to day basis. Engineers are always tasked with identifying and resolving problems as a team. An interview with Diego Morales, a service engineer with Nutricare S.A., provided some insight into what engineers do and how they work in conjunction with others.

${ }^{4}$ Own translation

5 Idem

6 Idem 
Morales elaborated on the importance of reports and their role in the process of requesting parts. He claimed that if his company did not have the necessary parts in stock, he would have to write emails to request replacements. In situations in which Morales had to order replacement parts, he said that the inclusion of a justification was essential for accounting purposes to show transparency to his company and its clients. Morales's account reveals that the duties and responsibilities of an engineer extend further than implementing theory. According to him, an engineer's ability to be a team player is also extremely critical.

Interests of primary stakeholders

Alejandro Jiménez, president of the Mechanical Engineering Students' Association, shed some light on what the university's expectations were of an English course designed for Mechanical Engineering students. After getting general information about the major and what it encompasses, Jiménez explained that the Mechanical Engineering program does not ask much of students with respect to their productive skills in English. However, from time to time students are required to use their receptive skills to gather information presented in English. He stated that professors recommend readings that complement the theories being studied, and students also have to listen to video tutorials in English to see these theories come to life. Jiménez further iterated that most of the software information and instructions are in English, suggesting that students need to possess the ability to read and understand this genre of writing.

Jiménez offered some insight into students' expectations after graduating in the field of Mechanical Engineering. He explained that most graduates aspire to work for industrial companies, and because of Mechanical Engineering's close relationship to biomedical engineering, students explore the opportunities of potentially working with the production of medical equipment. $\mathrm{He}$ stated that popular employers ranged from RECOPE to Boston Scientific and many more related to the Zona Franca in Costa Rica. Although Jiménez himself is still a student, he was able to provide some potential situations in which mechanical engineers would have to use English in occupational settings.

With respect to reading and writing in English, he stated that Mechanical Engineering jobs consist of e-mail correspondence, reading and creation of software, and reading and creation of designs. For speaking and listening, he mentioned situations such as conferences, listening to and defending design proposals, and job interviews. 
Results and discussion

Group Profile

Students' educational background

The group consists of 31 mechanical engineering students currently enrolled at UCR. A large percentage of the population, $68 \%$ to be exact, are between the ages of 21 and 26. A 58\% majority of this population is in its second or third year of the Mechanical Engineering program as seen in Figure 1.

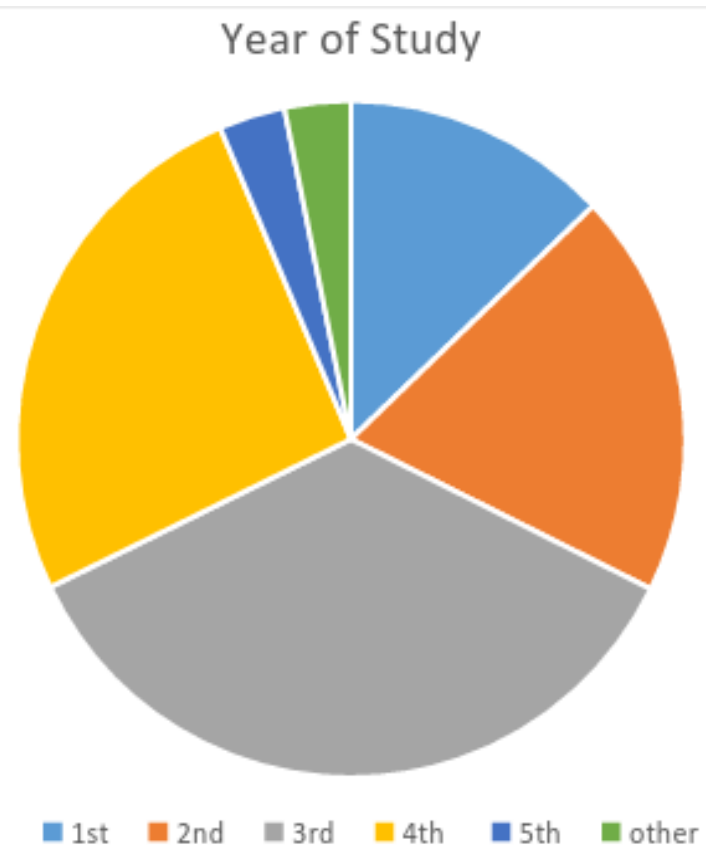

Figure 1: Students' enrollment according to year of study.

Description of the students' needs

The needs for this population are clearly differentiated between academic and occupational. In their academic life, Mechanical Engineering students are sometimes asked to manage receptive skills: reading and listening. There was no evidence that these students need productive skills like speaking or writing. Due to UCR's regulations, none of the materials in a foreign language can be evaluated; therefore, not all teachers use materials in English.

Once the students graduate and join the working force, the situation changes drastically. Costa Rica has particular economic, political, and social conditions that make the country very attractive for foreign investment. Most potential employers for the Mechanical Engineering students are 
international companies which use English as a lingua franca. Moreover, coworkers, business partners, and possible clients are also international and use English as their official language. Occupationally, these students will be required to speak and write in English very often. This represents a design challenge as there seems to be a divorce between their academic and occupational needs. Mechanical Engineering students do not ignore this reality, and their perceived needs focus on future work-related needs as shown in Figure 2.

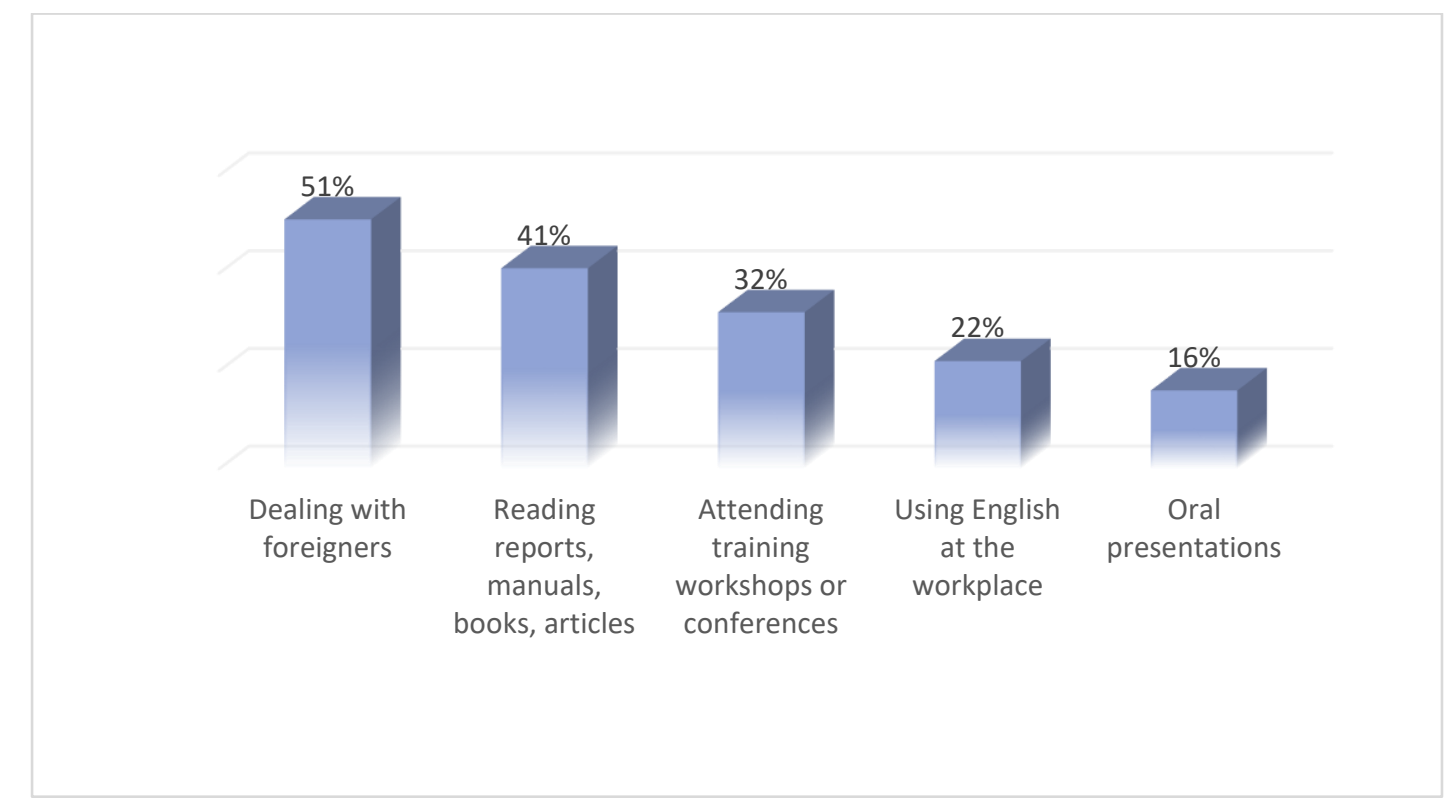

Figure 2: Perceived needs by Mechanical Engineering students.

This figure illustrates the percentage of students that indicated the above tasks as important. When asked openly which three activities would require students to use English the most-without giving them any prompt-, they replied in a fashion in which certain categories reflected common needs and interests, as shown in Figure 2. Consequently, this information was considered of paramount importance for the student-teachers when designing the goals and the contents of the course.

Description of the students' wants

Most students are aware of their future occupational needs in English and they want to improve their proficiency level. According to the initial questionnaire, most students would like to work on their speaking and writing skills. For instance, $87 \%$ of the population believes that 
speaking will be extremely necessary in their future work environment, and $77 \%$ considers that writing will be extremely necessary as well. More than $85 \%$ of the students mentioned varied ways of oral communication in English with supervisors, colleagues, or coworkers when asked for three activities that they will perform in their future work place. As part of their class dynamics preferences, $71 \%$ of students stated that they would like to work in pairs or groups and the same percentage would like to be asked to write in class. Also, $84 \%$ would like to participate in class orally. Open class discussions $(64 \%)$ and reading in class $(68 \%)$ were also mentioned by students.

Regarding the topics that students would like to cover in an ESP course, they could choose from several options, which were taken out their major syllabus. Students mentioned mechanical design (93\%), electro mechanics (77\%) and fluid mechanics $(77 \%)$ as the top three. When asked about their course expectations, specifically what they would like to learn, more than $80 \%$ of the students expressed that they would like to learn more technical vocabulary; more than $70 \%$ indicated that they would expect to improve their speaking skills, and approximately $40 \%$ explicitly mentioned that they would like to be able to explain the functioning of a machine.

\section{Description of the students' lacks}

As mentioned before, the syllabus for the Bachelor's and Licentiate Mechanical Engineering degree at UCR does not include any English course throughout the entire major. This is a very significant lack since the work market for these students seems to require English as a foreign language most of the times. Moreover, the students' previous training in English as a foreign language may vary considerably from subject to subject.

The lack of English training in the Costa Rican public educational system has been explored by the media since it represents one of the main complaints from employers (Brenes, 2012). Newspaper El Financiero has published several articles exploring the fact that the lack of English as a second language can make a difference between getting a well-paid job or not. The Commercial Director of Manpower Group commented for the newspaper: "Costa Rica has made important efforts to increase the technical training [...] but it's being left behind in English coverage" (Montero, 2015, para. 6) ${ }^{7}$. Mechanical Engineering students are well aware of this reality. They were asked to categorize the four macro skills on a difficulty scale, including very difficult, difficult, easy and very easy. For $61 \%$ of them, speaking is difficult. For $48 \%$ of the students, writing and

\footnotetext{
${ }^{7}$ Own translation
} 
listening were also described as difficult. When talking to the students before applying the DT, they also shared some personal anecdotes with each student teacher. They mostly talked about how their lack of English knowledge would have an impact on their professional lives since they felt that they would not be able to find a good job if they continued using the basic English knowledge they had from high school years, which supports Montero's claim.

Test results analysis

The diagnostic test is an instrument purposely designed to collect data that will not only indicate what proficiency level each student belongs to but also assist the student-teachers in finding an equilibrium between the identified needs, lacks, and wants of the target population.

According to the overall rating scale used in the DT, out of 20 Mechanical Engineering students, three are rated as beginner; eleven are rated as intermediate, and six as advanced. Figure 3 shows the percentages of the overall ratings of said students.

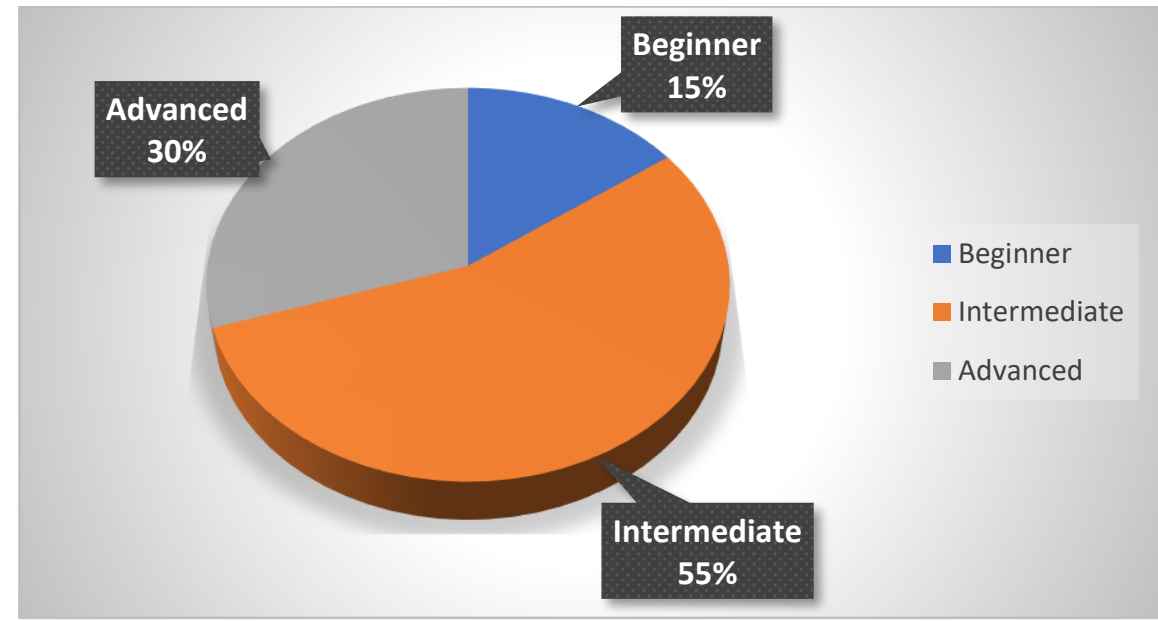

Figure 3: Diagnostic test overall rating scale results.

The figure illustrates the percentages of students rated as beginner, intermediate, and advanced. Of the students rated as beginners, one is taking fourth year courses and the other two are in their second year. Working with a majority of intermediate and advanced students, which represents $85 \%$ of the population, may favor certain types of tasks and assessment in the ESP course. On the other hand, the challenge with first year students is that even though they may have the English proficiency level, they lack experience with Mechanical Engineering concepts that may 
be key for future tasks in the course syllabus. The four macro skills analyzed individually displayed interesting results. Table 1 shows the summary of the rating scales by skill.

Table 1: Diagnostic Test rating scale per skill.

\begin{tabular}{lllll}
\hline Level & Listening & Speaking & Reading & Writing \\
\hline No. of Beginners & 1 & 6 & 0 & 2 \\
No. of Intermediate & 6 & 12 & 2 & 7 \\
No. of Advanced & 13 & 2 & 18 & 11 \\
\hline
\end{tabular}

Source: Diagnostic Test

As stated before, receptive skills are the ones currently used actively by these students in the Mechanical Engineering program. Accordingly, the listening and reading skills show a higher number of students rated as advanced and a lower number rated as beginner. Contrastingly, the productive skills — speaking and writing — have the higher number of beginners of the four macro skills. Speaking in particular holds a very low number of students rated as advanced. These data, together with the wants and needs analyzed in the first part of this report, support the fact that speaking tasks should be the main focus of the syllabus design. In previous interviews, one of the stakeholders had mentioned the "survival ability" of Mechanical Engineering students. This perception is reflected in the results for the reading skill. There are no students rated as beginner and it holds the highest number of students rated as advanced. It can be speculated that, taking into account the age range of the target population (97\% of them are in their twenties), reading in English has become an everyday task. Extra academic material, but also social media in its different forms, may seem to create an invisible but strong pressure to be able to understand English texts.

Listening was identified as one of their current academic needs. The DT results show that $65 \%$ of the students are very proficient when it comes to listening comprehension, as seen in Figure 4. This distribution indicates that listening tasks should have a fairly high level of difficulty. The one student who scored as a beginner will receive special assistance from one of the studentteachers in class in order to compensate for his/her low proficiency level. 


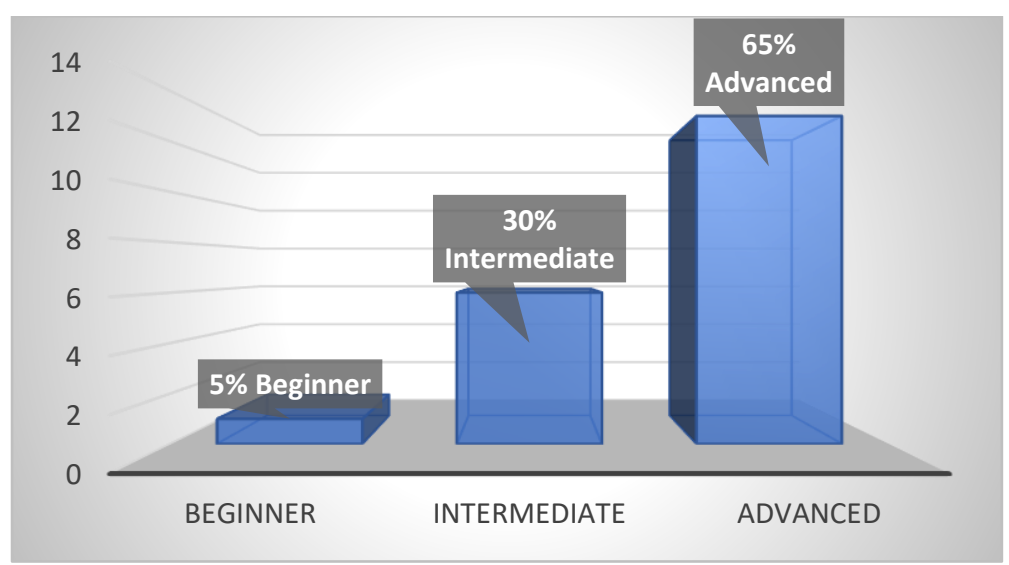

Figure 3: Diagnostic test overall listening rating

Speaking was identified as one of the future occupational needs. Mechanical Engineering students seem to be aware of their future prospects, and this is probably why $90 \%$ of them stated that speaking will be "extremely necessary" in their work in the first part of the Needs Analysis. This skill has the highest beginner rate of all, with $30 \%$, as seen in Figure 5. Only $10 \%$ of the population was rated as advanced in speaking.

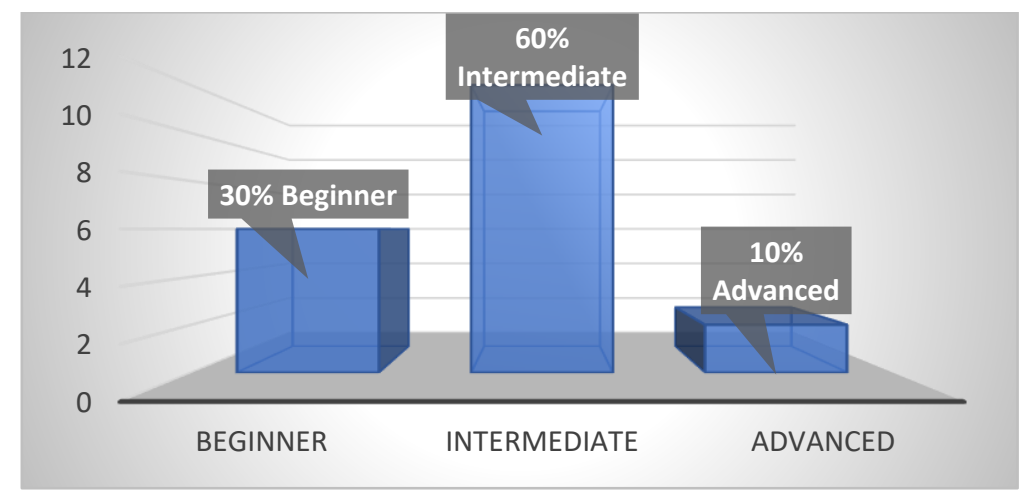

Figure 5: Diagnostic test overall speaking rating.

This suggests that future syllabus tasks should include several speaking-related activities and assessments to satisfy both the students' speaking needs and lacks. Based on this evidence, the students-teachers decided to pitch the level of the course and the tasks in general at the intermediate level, since $70 \%$ of the students would perform well at this level or above.

Reading was identified by the students as a current academic need. This was probably the biggest surprise of the DT's results since there are no beginner readers. In fact, $90 \%$ of the population was rated as advanced and only $10 \%$ as intermediate, as shown in Figure 6. This is a very valuable piece of information for the future syllabus design. The student-teachers can target academic needs by focusing more on listening tasks since, according to these data, Mechanical 
Engineering students manage reading comprehension very well. This does not mean that reading tasks will be left aside, as this skill was already identified as part of the academic needs. However, the rates shown by the DT allow a lighter emphasis on the reading comprehension tasks.

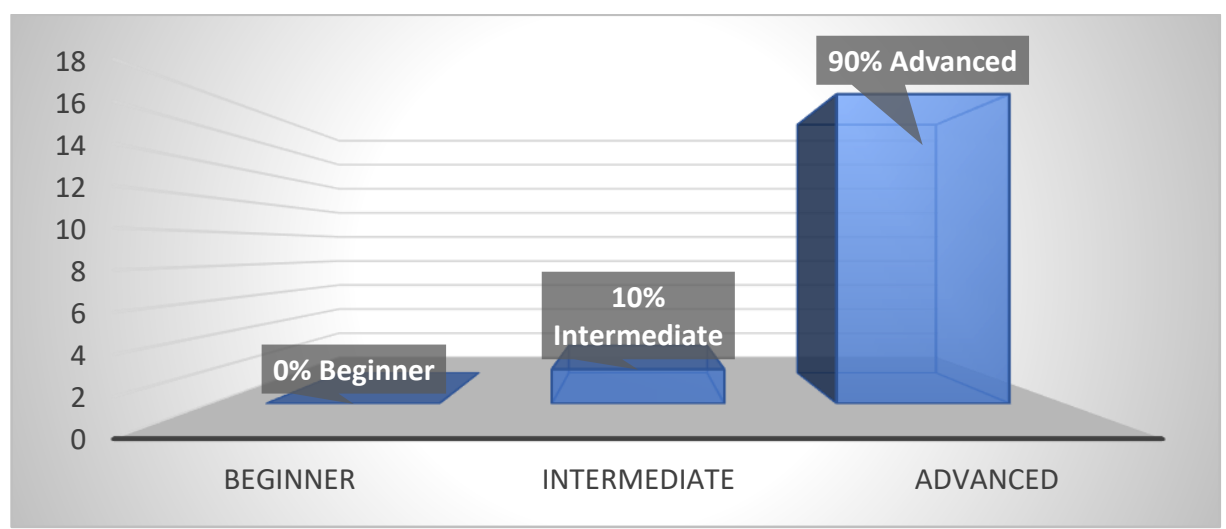

Figure 6: Diagnostic test overall reading rating.

Writing was identified as a future occupational need as well. This is the skill that holds more heterogeneous results because 11 out of 20 students were identified as advanced, seven as intermediate and two as beginner, as shown in Figure 7. This information admits a wide variety of difficulty levels in syllabus tasks which could be used in pre, post, and main tasks.

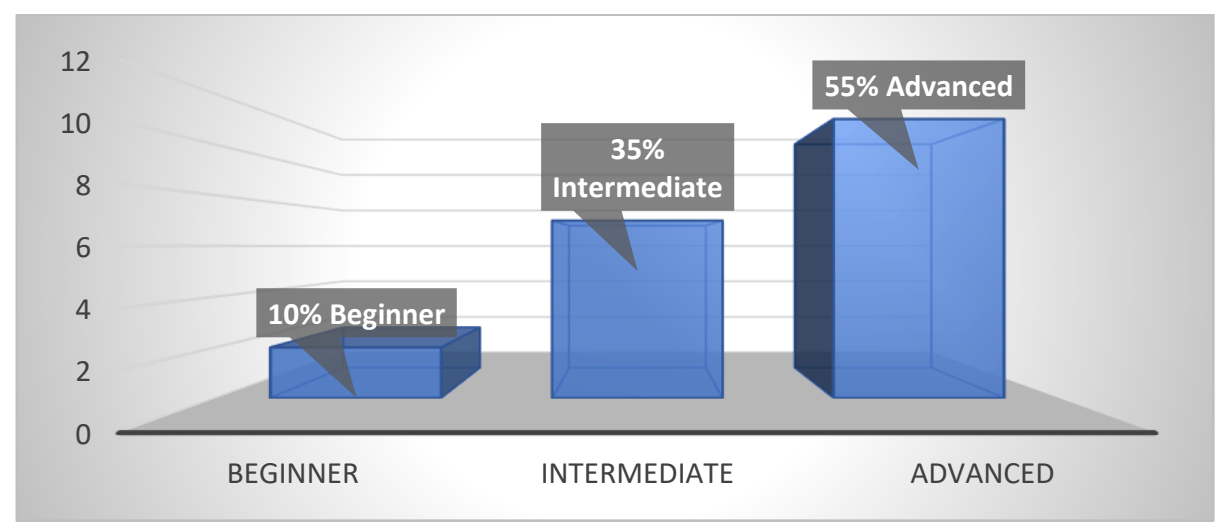

Figure 6: Diagnostic test overall writing rating

\section{Course Design}

As the outcome of the aforementioned results, the researchers elaborated the following course syllabus to meet the needs, wants, and lacks pointed out by both the students and the stakeholders. A student-friendly version of the course syllabus has been attached as Appendix A. 
The objectives, assessed activities, methodology, and the class calendar are part of this version of the course syllabus.

\section{Course Description}

This is an ESP course intended for Mechanical Engineering students at UCR. By the end of the course, the students will be able to comprehend texts associated with Mechanical Engineering and to communicate both orally and in written form at an intermediate English level within their field for academic and work-related purposes.

The class will be team-taught by three student-teachers who are language instructors. They will develop a task-based methodology throughout the course. This class will meet twice a week, two hours per day in room 114 at the School of Engineering (on Mondays) and in room 259 at the School of Modern Languages (on Wednesdays) from 5 p.m. to 7 p.m.

Statement of goals and objectives

Goal 1 (Unit 1- Getting it right)

By the end of this unit, the students will be able to use cognitive strategies and metacognitive strategies to improve their comprehension of both written and aural texts related to the fields of fluid mechanics and mechanical design.

General objectives:

a) By the end of the week, students will be able to guess meaning from written texts in the field of fluid mechanics while monitoring their learning progress.

b) By the end of the week, students will be able to identify the main idea from aural texts in the field of fluid mechanics by watching videos used as supplemental materials in class successfully.

c) By the end of the week, students will be able to guess meaning from context in the field of mechanical design by following written instructions on how to assemble a machine correctly.

d) By the end of the week, students will be able to identify the main idea from aural texts in the field of mechanical design by explaining how a machine works accurately. 
Goal 2 (Unit 2 - Job, here I come!)

By the end of this unit, Mechanical Engineering students will be capable of effectively briefing their information for a specific job position and participating actively in a job interview.

General objectives:

a) By the end of the week, the students will write their own résumé by analyzing samples and reviewing international format standards.

b) By the end of the week, the students will participate proactively in a job interview simulation by displaying cultural sensibility and knowledge of their own skills.

c) By the end of the week, the students will be capable of advocating for a specific proposal for a hypothetical work problem.

\section{Goal 3 (Unit 3: Going International)}

By the end of this unit, the students will be able to write e-mails to request information, order machine parts, and coordinate site visits, as well as successfully participate in meetings and conferences related to project presentations and updates.

General objectives:

a) By the end of the week, the students will be able to conduct machine related transactions via e-mail by using appropriate format, register, and functional language to request prices and information about machinery and parts.

b) By the end of the week, the students will be able to provide rationale for site visits by giving explanations via e-mail using appropriate format, register, and functional language.

c) By the end of the week, the students will be able to present new projects as well as project updates about advancements using appropriate structures and functional language.

d) By the end of the week, the students will be able to take part in meetings by effectively using strategies for interrupting and taking turns.

\section{Methodology}

As described by Willis (1996) and by Pica, Kanagy, and Falodun (2009) in Richard and Rodgers (2001), to obtain the results desired in TBLT, task types, such as listing, ordering, comparing, problem solving, jigsaws, info-gaps, decision-making, and opinion-gaps activities can 
work in benefit of the learners to maximize their experience using this method (p. 234). By following what has been proposed in the TBLT approach, learners are said to be more engaged; hence, tasks seem to be more interactive. These can be pedagogical or real-world tasks, but the idea is that in the end both types have the same function: to simulate real-life features that learners will perform at some point outside of the class.

Learners who are part of a process in which this method is applied should perform three main roles (defined in Richard and Rodgers, 2001, p. 235). Initially, they must know they will be group participants. This means that they will often be asked to work in pairs or groups. They will develop speaking strategies so that they can communicate effectively with their classmates. Another role is to work as monitors. Learners should be able to monitor their own production and apply strategies to repair their speech when facing linguistic breakdown. Finally, learners are motivated to take risks. They need to know that when participating in tasks they should not worry about making mistakes. They are told that making mistakes is part of the learning process and that they need to focus on delivering a message, not on working on perfect grammar.

Richard and Rodgers (2001) also mention that teachers using the TBLT method should perform three main roles (p. 236). The first one is selecting and sequencing tasks. Teachers must pay attention to the order in which they place their tasks to address specific functions. For example, placing a warm-up activity clearly at the beginning must be done to activate schemata. Secondly, teachers should prepare learners for tasks. Teachers should not start a class with the main task because, most probably, students will not be able to successfully perform it without preparation. Finally, as mentioned before, teachers should help students "focus on form" (Richard and Rodgers, 2001, p. 236), which implies raising consciousness in students through pre-tasks and guided tasks so that students can "notice critical features of the language they use and hear" (Richard and Rodgers, 2001, p. 236).

\section{Assessment}

As the present course is ESP focused and is framed under a task-based approach, all of the formal assessment activities will focus on having students performing tasks, which can also be considered as part of performance-based assessment (Brown, 2004, p. 10). This approach proves relevant for the student-teachers as, under this type of assessment, "students are assessed as they perform actual or simulated real-world tasks" (Brown, 2004, p.10). The student-teachers firmly 
believe that such assessment is the most beneficial for their students as they will be ensuring high content validity, which is achieved "because learners are measured in the process of performing the targeted linguistic acts" (Brown, 2004, p. 11). Additionally, by formally and carefully crafting these types of interactive tasks, the student-teachers can make sure that said tasks "can approach the authenticity of real-life language use" (Brown, 2004, p.11). Powered by the Task Based Approach, the term authentic assessment gained relevance in the academic world. This kind of assessment focuses on meaningful real-life tasks in order to determine how much students have learned. One of the main characteristics of authentic assessing is that it uses "engaging and worthy problems ..., in which students must use knowledge to fashion performances effectively and creatively.

The tasks are either replicas of or analogous to the kinds of problems faced by ... professionals in the field" (Wiggins, 1993, p.40). This type of assessment emphasizes what the students can $d o$, and not what they know, although they are intrinsically related. Thus, teachers can direct the assessing instruments to these principles and evaluate the actual proficiency level of the students when performing specific real-life tasks.

Table 2 shows the types of assessment to be used by the student-teachers during the course, and all the assessments in it will be administered in the chronological order presented in the table. This order runs parallel to the units presented in the course so that each assessment will be related to the material covered. For the purpose of the course, the students will be evaluated based on their performance in five different assessments as detailed in Table 2.

Table 2: Evaluated activities during the second semester.

\begin{tabular}{cc}
\hline Type of assessment & Percentage \\
\hline 1. Academic task (integrating reading and listening) & $20 \%$ \\
2. Oral Presentation I (defending a project proposal) & $20 \%$ \\
3. Written mini projects (writing an e-mail and a résumé) & $15 \%$ \\
4. Job interview simulation & $20 \%$
\end{tabular}


5. Final Speaking Project (participating in meetings and conferences; specific $25 \%$ tasks coordinating site visits, updates, ordering machine parts)

As previously mentioned, the bulk of evaluation falls under the category of performancebased assessment. The first assessment is an academic performance task which focuses on reading and listening. The types of authentic materials for the academic performance task will be similar to that of the diagnostic test; however, for the academic performance task student-teachers anticipate that students will employ the cognitive and metacognitive strategies learned during the first unit. The students will be asked to watch authentic videos and read authentic written texts to build a two-stage balloon rocket in class.

The objective of this assessment is to help students become more proficient readers and listeners to tackle their immediate academic needs, since, as explained in previous sections, Mechanical Engineering students are exposed to written and aural texts in class, but they do not have the necessary tools to deal with these texts. The academic performance task will have a 20 percent influence on the students' final grade due to its immediate importance.

The second assessment is an oral presentation in which students have to defend a project proposal. This assessment is another authentic task that encourages students to use the vocabulary and grammatical structures presented in the second unit. This project proposal is not unlike the project presentation that students had to do for the diagnostic test; however, students should be better equipped with strategies and new vocabulary learned in the course for this assessment. This first oral presentation will have a 20 percent influence on the students' final grade because of the importance and relevance of this task in a job setting.

The diagnostic test also revealed that 90 percent of students were at the intermediate or beginner level for speaking, suggesting that speaking is a skill that requires more polishing than the other macro-skills. The third assessment contains two written mini projects that entail the reading and writing of work-related e-mails and the creation of a résumé. This assessment reflects an authentic task faced by mechanical engineers on a day to day basis. Also, the development of the résumé will be carefully guided by the student-teachers to aid students in the formation of a well-designed and accurate description of themselves. The written mini projects will have a fifteen percent influence on the students' final grade. The student-teachers agreed on this percentage 
because the results of the diagnostic test revealed that 90 percent of the students were intermediate or advanced writers, proving that writing was not as challenging as some of the other skills.

The fourth assessment is the job interview simulation. As previously mentioned, the assessments run parallel to the course. The job interview simulation will be evaluated after the completion of Unit 2: Job, here I come! This assessment intends to replicate a real-life situation for students, especially for those in their final year. The job interview will have a 20 percent influence on the students' final grade mainly because of the great deal of material it covers.

The fifth and last assessment is the final oral presentation. This assessment aims to evaluate the students' ability to participate in meetings. According to stakeholders, mechanical engineers have to work as a team to resolve problems. This being the most difficult assessment, the studentteachers decided to include it as the final assessment. This would allow students to use all the language and strategies acquired throughout the course to successfully complete the task. The final oral presentation will have a 25 percent influence on the students' final grade, the highest percentage of all the assessments. This is due to its difficulty and importance as stated by the stakeholders.

One of the main characteristics of assessment is that it is an on-going process (Brown, 2004). Having only a final course evaluation may prevent teachers from correcting anything that may not be working really well on the course. Students' opinion throughout the course is a great source of input to modify class planning for the future. As stated previously, the course Gear Up has three units. At the end of each unit, students will be given a questionnaire that will explore their preferences and opinions about the contents, difficulty, and organization of each specific unit and assessed activity. This will allow student-teachers to make the necessary adjustments for the following units. Most of the items use a perception scale that is described at the beginning of the questionnaire. This kind of scale is meant to make the questionnaire user friendly. Also, there are some open-ended questions so that students can express their opinions freely and provide suggestions, comments, or complaints.

The items assessed in the questionnaire are related to the course objectives in general but also to the teaching approach, in this case, TBLT. This instrument will be administered online. In an ESP course, students are the final clients. Their needs, lacks, and wants were explored in the previous Needs Analysis and the entire course was designed based on them. However, as in any other corporate relationship, the clients should have the option to evaluate their providers, in this 
case, the student-teachers on a regular basis. Just like the previous assessing instrument, the student-teachers decided to create one more instrument in which the teachers' performance is the one being evaluated, not the entire course or unit. The items evaluated also go along with ESP, TBLT principles, and performance-based assessment; for example, teaching talking time, class materials, or feedback. There are also some open-ended questions so students can refer to a specific student-teacher or situation in general. This instrument will also be administered online.

\section{Conclusions}

Gear Up is designed to provide students — with an intermediate or advanced level of Englishwith the stepping stones required to communicate efficiently within the field of Mechanical Engineering at work in national and multinational-related settings. The inclusion of authentic academic and occupational tasks addresses immediate and long-term needs of the population, as the course promises to fill the language void expressed by Mechanical Engineering students. In addition to presenting rich and relevant content, Gear Up strives to meet students' expectations regarding its overall enjoyment by including topics they deemed as relevant and motivating, such as electro mechanics, fluid mechanics, and mechanical design within the three units to be developed. The course is filled with a variety of dynamic tasks to ensure that students have an enriching experience. Due to Gear Up's emphasis on communication strategies, the studentteachers anticipate that it will be an invaluable asset to the professional development of the course's participants.

\section{References}

American Council on the Teaching of Foreign Languages. (2015). "NCSSFL-ACFTL Can-Do

Statements: Progress Indicators for Language Learners" Retrieved from: https://www.actfl.org/sites/default/files/pdfs/Can- Do_Statements_2015.pdf

American Council on the Teaching of Foreign Languages. (2012). Oral Proficiency Interview Tester Training Manual. Swender, E. \& Vicars, R. (Eds.). Buffalo, NY: ACTFL.

Brenes, C. (2012). Talento Escaso Reta A Zonas Francas. El Financiero.Retrieved from http://wvw.elfinancierocr.com/ef_archivo/2012/junio/10/negocios3190319.html

Brown, H.D. (2004). Language assessment: Principles and classroom practices. White Plains, NY: Pearson Education. 
Coombe, C., Folse, K., \& Hubbley, N. (2007). A practical guide to assessing language learners. Michigan: The University of Michigan Press.

Huba, M. E., \& Freed, J. E. (2000). Learner-centered assessment on college campuses: shifting the focus from teaching to learning. Boston: Allyn and Bacon.

Ingeniería Mecánica. (n.d.). UCR. Retrieved from http://www.eim.ucr.ac.cr/

Montero, J. (2015). Escasez de talento aumento en Costa Rica. El Financiero. Retrieved from http://www.elfinancierocr.com/economia-y-politica/Escasez- $\quad$ talentoaumento_0_556144391.html

Richards, J. C., \& Rodgers, T. S. (2001). Approaches and Methods in Language Teaching. Second Edition. NY: Cambridge University Press.

Skehan, P. (1998). Task-Based Instruction. Annual Review of Applied Linguistics, 18, 268-286. doi:10.1017/s0267190500003585

Wiggins, G. P. (1993). Assessing student performance. San Francisco: Jossey- Bass Publishers. 


\section{Appendix A}

Student Syllabus

Universidad de Costa Rica

Maestría en la Enseñanza del Inglés como Lengua Extranjera

Gear Up - English for Mechanical Engineering Students

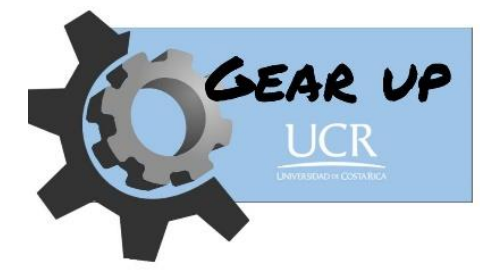

Instructors: Elizondo, J., Pilgrim, Y., \& Sánchez, A.

Mondays \& Wednesdays from 5 p.m. to 6:50 p.m.

\section{Course Description}

This is an ESP course intended for Mechanical Engineering students at UCR. By the end of the course, the students will be able to comprehend texts associated with Mechanical Engineering and to communicate both orally and in written form at an intermediate English level within their field for academic and work-related purposes. The class will be teamtaught by three student-teachers who are language instructors. They will develop a task-based methodology throughout the course. This class will meet twice a week, two hours per day in room (TBA). Attendance is not mandatory or assessed; however, any student with more than 3 absences will not qualify to obtain the university's certification for the course.

\section{Goals and Objectives}

\section{Unit 1- Getting it right}

By the end of this unit, the students will be able to use cognitive strategies and metacognitive strategies to improve their comprehension of both written and aural texts related to the fields of fluids and mechanical design.

\section{Unit 2 - Job, here I come!}

By the end of this unit, mechanical engineering students will be capable of effectively briefing their information for a specific job position and participating actively in a job interview.

\section{Unit 3: Going International}

By the end of this unit, the students will be able to write e-mails to request information, order machine parts, and coordinate site visits, as well as successfully participate in meetings and conferences related to project presentations and updates.

\section{Methodology}

The course is divided into three units. The students will carry out tasks in class strictly related to their reality as Mechanical Engineering students and future professional Mechanical Engineers. These tasks will integrate the four macro skills: speaking, listening, reading, and writing. The tasks will be done individually, in pairs, or groups. They will include class presentations, debates, role-plays, reading and listening comprehension activities, writing, among others.

\section{Assessment}

Each of the units will be assessed according to the goals established. 
- Academic task

(reading and listening academic task)

- Oral Presentation I

(presentation of a previous academic project)

- Job interview simulation

- Written mini projects (e-mail and resume)

- Oral Presentation II

(participation in meetings and conferences; specific tasks coordinating site visits, updates, ordering machine parts)

\section{Class information}

$\checkmark$ The students are not required to bring a dictionary to class; however, having one, either physically or electronically, can be useful.

$\checkmark$ The students are not to pay for any of the material or the certificate at the end of the course.

$\checkmark$ Punctuality and class participation are expected of all students.

\section{Course Calendar}

\begin{tabular}{|c|c|c|c|}
\hline Week 1 & Unit 1 & Reading about fluids & \\
\hline Week 2 & Unit 1 & Listening about fluids & \\
\hline Week 3 & Unit 1 & $\begin{array}{l}\text { Assembling a machine in class } \\
\text { and watching videos about } \\
\text { mechanical design issues }\end{array}$ & \\
\hline Week 4 & Unit 1 & Practicing for academic task & Academic task \\
\hline Week 5 & Unit 2 & Writing a résumé & \\
\hline Week 6 & Unit 2 & Defending a proposal & Hand in resume \\
\hline Week 7 & Unit 2 & $\begin{array}{l}\text { Presenting previous academic } \\
\text { project }\end{array}$ & OP\#1 \\
\hline Week 8 & Unit 2 & Participating job interviews & \\
\hline Week 9 & Unit 2 & $\begin{array}{l}\text { Practicing job interview } \\
\text { simulations }\end{array}$ & $\begin{array}{l}\text { Job interview } \\
\text { simulation }\end{array}$ \\
\hline Week 10 & Unit 3 & Writing e-mails & \\
\hline Week 11 & Unit 3 & Writing e-mails & Sending an e-mail \\
\hline Week 12 & Unit 3 & Presenting a project & \\
\hline Week 13 & Unit 3 & Participating in meetings & \\
\hline Week 14 & Unit 3 & Participating in meetings & \\
\hline Week 15 & Review & & \\
\hline Week 16 & & & OP\#2 \\
\hline
\end{tabular}

